\title{
Smartphone Screen Recording Apps: An Effective Tool to Enhance Fluency in the English Language
}

\section{Aplicaciones de grabación de pantalla para teléfonos inteligentes: una herramienta eficaz para mejorar la fluidez en el idioma inglés}

\author{
Catherine Pardo Soto' \\ Cecilia Cisterna Zenteno ${ }^{2}$
}

\author{
Citation/ Para citar este Artículo: Pardo Soto, C., \& Cisterna Zenteno, C. (2019). Smartphones Screen Recording Apps: An Effective Tool to \\ Enhance English Language Fluency. Colomb. Appl. Linguistic. J., 21(2), pp. 208-229. \\ Received: 07-Dec.-2018 / Accepted: 18-Sep.-2019 \\ DOI: https://doi.org/10.14483/22487085.14202
}

\begin{abstract}
This investigation intended to assess the effectiveness of smartphone video recording applications in increasing the speaking fluency of students of English as a foreign language (EFL). The study was conducted on a group of thirtyone 7th grade students aged between 12 and 13 years and enrolled in a subsidised school in Chile. The convenience sampling method was employed to select the participating students and the participants' manner of communication was analysed through several English speaking sessions in which they used their smartphone video recording applications. Data collection was undertaken through pre- and post-speaking tasks used in this action research. The collected data were examined using a specific analytic rubric and a focus group interview. Data analysis was accomplished via two techniques: a simple percentage analysis and a thematic examination. The findings revealed an increase in the speaking fluency of the participating students, specifically with regard to the 'pace' criterion identified in the analytic rubric used to assess improvement in the speaking performance of students as evidenced by video recordings. Also, the results of the focus group interview conducted with the students evidenced the participants' positive response to the use of smartphone recording video applications in ameliorating their English communication fluency.
\end{abstract}

Keywords: smartphones, video recording app, fluency, speaking activities

\section{Resumen}

Esta investigación pretende evaluar la efectividad de las aplicaciones de grabación de vídeo en teléfonos inteligentes para aumentar la fluidez oral de los estudiantes de inglés como lengua extranjera (ILE). El estudio se llevó a cabo en un grupo de 31 alumnos de $7^{\circ}$ grado de entre 12 y 13 años de edad, matriculados en una escuela subvencionada en Chile. Se utilizó el método de muestreo de conveniencia para seleccionar a los estudiantes participantes y se analizó la forma de comunicación de los participantes a través de varias sesiones de habla inglesa en las que utilizaron las aplicaciones de grabación de vídeo de sus teléfonos inteligentes. La recopilación de datos se llevó a cabo a través de las tareas de conversación previas y posteriores, asignadas para esta investigación-acción. Los datos recolectados fueron

1 Universidad de Concepcion, Chile. ORCID iD https://orcid.org/0000-0002-8751-9344. catherine.v.pardo@gmail.com

2 Universidad de Concepción, Chile. ORCID ID https://orcid.org/0000-0001-9707-154X. cecisterna@udec.cl. 
examinados usando una rúbrica analítica específica y una entrevista de grupo focal. El análisis de los datos se realizó mediante dos técnicas: un análisis porcentual simple y un examen temático. Los hallazgos revelaron un aumento en la fluidez del habla de los estudiantes participantes, específicamente con respecto al criterio de "ritmo" establecido en la rúbrica analítica utilizada para evaluar la mejora en el rendimiento oral de los estudiantes, tal y como se evidencia en las grabaciones de vídeo. Además, los resultados de la entrevista de grupo focal llevada a cabo con los estudiantes pusieron de manifiesto la respuesta positiva de los participantes al uso de aplicaciones de grabación de vídeo en teléfonos inteligentes para mejorar su fluidez en la comunicación en inglés.

Palabras clave: teléfonos inteligentes, aplicación de grabación de vídeo, fluidez, actividades de conversación

\section{Introduction}

This action research investigation describes the implementation of a technology-based tool to the process of the instruction of English as a foreign language (EFL) in a Chilean classroom. It investigates the effects of smartphone video recording applications (no particular brand) on the improvement of the verbal English fluency of a group of $7^{\text {th }}$ graders. This research project was conducted in a subsidised primary school located in the area surrounding Concepción, Chile. The idea for this study emerged from a review of several reports of the educational improvements observed in the communicative skills of EFL learners through the use of smartphone video recordings, specifically the enhancement of fluency in speech (Foremar, 1999; Katchen, 1991; Lynch \& Maclean, 2003; Murphy $\&$ Woo, 1998). The report of the outcomes of a feedback tool also drove the desire for an empirical assessment of the subject (Tuga, 2013; Glen, 1996).

The present study analyses the improvement in the speaking fluency exhibited by a group of $7^{\text {th }}$ graders in a speech task. The participants had to make an oral presentation that followed a model presented by the teacher.
This paper is divided into six parts: firstly, the identified problem is presented along with the corresponding aims of the study; second, the conceptual framework that supports the identified problem and objectives is addressed; third, the methodology is detailed, including the stages of the action research implementation, the data collection techniques and the data analysis; fourth, the main findings of the investigation are assessed and presented; and finally, the paper closes with the interpretation of the results, the concluding statements and recommendations for future research.

\section{Problem statement}

Innovative technologies such as the Internet, video conferencing, podcasts, videos and speech recognition software are currently considered the best tools for developing speaking skills. Presently, these technologies are being introduced into EFL classrooms to support and to improve the English speaking skills of learners. Computer-based training, online learning and mobile technologies are some of the useful means of obtaining access to these instruction tools and technological applications, also known as 'apps,' have been built as useful resources to help students improve their language skills, particularly oral communication (Bahadorfar E Omidvar, 2014).

In 1998, the Ministry of Education in Chile (MINEDUC) presented an overall reform of the core curricula stating clear learning objectives for the different subjects in the syllabus. A list of fundamental educational objectives to be developed in each year of learning was thus also presented for the language discipline of English. The new curriculum placed primary emphasis on the development of receptive skills (reading and listening skills). However, it did not stress the progression of productive skills (speaking and writing skills).

The Ministry of Education and the English Opens Doors Programme conducted studies on language learning. In 2004, a national initiative to promote the development of English language learning was launched in Chilean schools. This 
plan proposed that students should reach a specific level of communicative competence in the English language at various stages: $7^{\text {th }}$ graders were mandated to achieve an A1 level of proficiency in accordance with the Common European Framework of Reference while $11^{\text {th }}$ graders, who represented the last year of secondary education, were required to attain the B1 proficiency level.

The Key English Test (KET), a diagnostic tool, was applied in 2005 to 10th graders to assess the English language proficiency of Chilean students. This test focused on the assessment of receptive skills, but it did not consider the progression of speaking and writing skills since the applied tool was an adapted version of the international instrument (Agencia de la Educacion, 2005). The results of that test revealed that by the end of their high school education, only $5 \%$ of the students achieved the level of proficiency required by the Ministry of Education (Ministry of Education, 2004).

In 2010, the Ministry of Education changed the test and applied the Test of English for International Communication Bridge Test to obtain another perspective of the performance of high school students in the subject of English language learning. This English diagnostic test measured listening and reading skills, and once again eliminated the examination of the development of speaking skills. Hence, Chilean students in secondary schools are given very few opportunities of using the English language in authentic communicative situations. This deficiency hinders the development of their communicative skills, especially in the productive context.

The current study emerges from a specific issue observed during the English lessons to $7^{\text {th }}$ graders attending a subsidised primary school in Coronel-Chile. The identified problem pertains to the difficulty these students experienced in developing the speaking tasks assigned during the course of the English lessons. In the particular instance, the students were asked to make a short oral presentation about their favourite TV show. The teacher noticed that whenever the students were asked to make oral presentations, they tended to read aloud the presented information instead of speaking fluently to the class. The school was very interested in promoting the development of the English language in its students and its management considered the idea of implementing different types of speech related activities as a way of helping students to improve their fluency in the language. Such activities included the organisation of events such as English festivals, an English week, and English talent shows that were focused on enhancing the speaking skills of the students. The English teacher observed that during their breaks, students were regularly using their smartphones to record videos in their mother language to talk about their preferences and that they were highly motivated by the prospect of sharing the videos with their classmates.

The study reported in the present paper was devised in response to the felt problem of determining a way of enhancing the students' English speaking fluency. It investigated the effectiveness of smartphone video screen apps to improve their level of fluency as they made oral presentations in the classroom. The action plan was executed in six sessions in which the participating students were asked to record short videos about famous TV shows. These videos were required to include advertisements, interviews, and other mandatory forms of speech communication (See Appendix 5). Students worked in small groups with the aim of improving their fluency in the target language. Smartphone video cameras apps were selected for the recordings because these are commonly used by teenagers in their daily lives and are more accessible to them than the classical video camera.

\section{Conceptual framework}

\section{The role of technology in EFL classrooms}

EFL teachers should always consider the use of technology in the classroom along with their traditional pedagogy because such current tools can change the classroom environment and allow instruction to become more aligned with the extracurricular interests of the learners (Mishra $E$ Koehler, 2006). Nowadays, technology and social media exert an immense influence on education 
and have introduced major changes to teaching methodologies (Ahmadi \& Reza, 2018). Social networks such as Facebook, YouTube, Google, Twitter, Instagram and WhatsApp have turned into useful tools that connect and increase interactions between students and teachers, transforming the way we learn and think. If educators take the initiative to integrate these resources into their classroom pedagogy, they can obtain meaningful benefits in the learning attained by their students.

$21^{\text {st }}$ century educators must incorporate technology in their lessons to prepare students for the upcoming future and to encourage schools to integrate a dynamic approach that includes the use of the four C's: Communication, Critical Thinking, Creativity and Collaboration (Sloan, 2015).

English and technology have become essential tools to support language learning and to encourage the social participation of non-native speakers (Jung, 2006). Nevertheless, technology cannot improve language learning on its own; instead, it should be utilised as a complement to conventional instruction methods. The actual enhancement of learning is dependent on how technology is used by students in their process of acquiring skills. It is thus the teacher's responsibility to select the right technology to support the study material that must be reviewed. If the use of technology is appropriately matched to the context in which language learning takes place, the achievement of learners will increase significantly along with other aspects such as their motivation, collaboration and autonomy (Jurich, 2001; Lee, 2000 in Jung 2006).

The use of video recording apps can be mentioned in recounting the benefits of using technology through meaningful interaction and in enumerating its contribution to the enhancement of the productive skills pertaining to the English language. When students can record themselves in the EFL classroom, they are able to become aware of their body language, to become more self-critical, and to analyse their speaking abilities and other productive procedures relating to language learning (Katchen, 1991). Additionally, Joe Dale (2014), a former language teacher, declares that recording videos can be a vehicle for instruction both in and out of the language classroom interaction. According to him, creating videos in a foreign language draws upon multiple intelligences, promotes creativity and fosters collaboration. Further, the assignation of videography related tasks accords students a degree of autonomy over their productive work and thus, increases learner engagement.

The present study incorporates the use of mobile apps to record videos keeping in mind the significant benefits a video recording app can bring to language learning as a resourceful tool that may contribute effectively to the promotion of English speaking fluency in foreign language learners.

\section{The smart phone: a useful educational tool to support EFL classroom activities}

Contemporary youngsters are very attached to their smartphones and show natural enthusiasm when they are allowed to work with them during their lessons. However, the smartphones are also known to cause distractions in the classroom and teachers sometimes find it difficult to control and monitor smartphone use in their classrooms. According to the Sheffield Hallam University (2014), the current teaching processes must provide student-facing personnel more guidance in the responsible and strategic use of social media to support learning.

Smartphones support discrete apps that can be used for learning. These include the voice recorder, timer, camera, dictionaries and the video recorder, to name only a few. Some researchers assert that the use of video recordings in EFL classrooms can be useful as an educational tool (Foremar, 1999; Katchen, 1991; Lynch \& Maclean, 2003; Murphy $\varepsilon$ Woo, 1998) and can also function as a feedback tool (Tuga, 2013; Glen, 1996). If used appropriately, video recordings can provide significant benefits and effect positive changes in the oral communication abilities of students. The enthusiasm of most learners is found to increase when they are given opportunities to record their speech performances, receive feedback, and can follow their improvements via an audio-visual record (Katchen, 1991). Opinions relating to the use of smartphones in educational settings differ and scholarly discussions on the topic are ongoing (Gilroy, 2004 E Taylor, 2008). A study 
conducted at the Pew Research Centre (Lenhart, Ling, Campbell \& Purcell, 2010) found out that 65 percent of teenagers bring their phones to school despite prohibitions that may be put into place and the smartphone has become the favourite means through which American teens communicate with each other. Therefore, smartphones and technology accomplish many important functions such as helping EFL students enhance their own learning, aiding them in making future decisions and assisting them in undergoing authentic learning experiences.

\section{Oral fluency development in the English language}

Fluency is defined as the ability to achieve the communicative intent without too much hesitation and too many pauses to cause barriers in communication (Crystal, 1977; Byne, 1986; Nation, 1991). The word 'fluency' comes from the Latin fluentem, which means 'to flow'. According to Laura K. Lawless (2018), an online educator, fluency implies the ability to have a conversation comparable to that of a native speaker.

The present study will refer to the term 'fluency' as specifically alluding to oral or speaking fluency in the language, measuring both the production and the reception of speech because a fluent speaker must also be able to understand and to respond to others in conversation.

According to the conducted literature review, becoming fluent involves the following aspects that are relevant when a person is speaking naturally:

a) Expression and volume ensure that a presenter understands vocal modulation and learns its effective use. This element may also be called the 'delivery' of a speech (Schmidt, 1992, p.358), and fluency is deemed to manifest when a speaker can deliver information directly from the mind and without the intervention of other tools such as written material.

b) Phrasing (Skehan, 2009) relates to any frequently repeated or memorable group of words, usually shorter than a sentence in length and complexity. c) Smoothness pertains to the ease or regularity (Housen, Kuiken, $\mathcal{E}$ Vedder, 2012) with which a speaker can deliver spoken content. This component regulates the common notion of fluency as the continuity of the verbalisation of a speech (Koponen E Riggenbash, 2000).

d) Pace is a key factor in achieving effective communication and it must be appropriate to the content, the mood, the occasion and the capabilities of the audience. When people talk too fast, listeners cannot process or understand the information they share; when people talk too slowly, the audience becomes impatient and bored (Zimmer, 2008).

\section{Smartphones video recording apps as a tool to improve oral fluency}

Video recordings are a very useful resource used every day by students of different ages. Hence, video recording apps present a beneficial means for students to rehearse and to polish their EFL fluency (Keddie, 2018). Teachers are including more videos created by students in their classes than ever before since students are more accustomed to using videos, and teachers can take advantage of this interest and make their lessons more appealing (Lansford, 2014). Hence, learners can receive all their L2 input on their smart devices. Videos can compensate for the absence of the availability of the target language in non-native environments, especially in language learning pertaining to real-life situations and contexts (Mercado, 2017).

A study on the development of fluency in students (Diyyab, 2014) reveals that integrating video recordings with the speaking activities slated for EFL learners offers several advantages: students can observe their own performances and those of their friends; they can repeatedly self-assess video recordings of their speech delivery; they can develop a critical distance and identify the gaps in their speaking skills, they can view the videos and conceptualise and rehearse improvements; and teachers can use the videos to indicate tips and techniques that would improve the English fluency of their students (Kirkgoz, 2011).

Further, a video recording can become part of the language input of learners and educators 
can indicate such a tool as a model on which to base learner output. Many teachers have reported significant results from student-produced activities that were grounded in a previously presented audio-visual model and students were asked to produce their own version of the original (Lansford, 2014). The access of learners to video cameras is ever-increasing and students regularly record videos in Spanish on topics that are of their interest. They are also seen to perform live 'videos' in the classroom. Teachers can take advantage of this natural propensity of young people in the classroom and can turn their lessons into successful learning sessions. Taking into account the advantages presented by video recordings and considering the fact that students currently use this technology frequently both inside and outside the classroom, the present study aims at engaging students through the utilisation of this mobile app for EFL learning purposes and to help them improve their English speaking fluency.

\section{Mobile assisted language learning (MALL)}

Smartphones offer specific advantages in the context of learning and offer specific applications that support the development of EFL skills such as reading, listening, speaking and writing. These apps attend primarily to advancing authentic language learning through smart systems (Kukulska-Hulme, 2012). Further, research results have demonstrated positive attitudes and have evidenced great interest in students in using technology and applications in learning to speak a foreign language (Baleghizadeh E Oladrostam, 2010).

According to a recent study (Sun., Lin, You, Shen, Qi \& Luo, 2017), most non-native students who are learning a second language lack sufficient opportunities to practice their English speaking skills within or outside classrooms environment. Hence, educators must find technological solutions connected to learning that increases the oral communication skills of learners. In this context, mobile assisted language learning is particularly of interest because it is thought to be a meaningful way of practising spoken English and it can empower young learners to speak the foreign language more frequently and confidently.

\section{Methodology}

\section{Participants}

The sample comprised 31 participants in all, whose ages ranged between 12 and 13 years old, all of them belonged to a 7th grade class from a subsidized Chilean school located in Coronel, Chile: 15 were female and 16 male. All the students were tested at the elementary level of English language proficiency and received four hours of English learning per week. Their English lessons emphasised the communicative approach. The average class grade in the subject of English language acquisition was 6.2 (measured on a scale ranging from 1.0 to 7.0 ). Five new students were introduced to the class in the current year, while the rest of the students (26 students) in the class were enrolled in the studied school for more than three years. The participant sample was selected using a criterion that was deemed relevant by the researcher (Mason, 2017). According to Tejero (2006) non-random sampling emphasises that all participants of the investigation must be accorded equal opportunities. On this basis, the author of this paper selected a convenience sample that involved all the participants of the study to provide a clear rationale and to respond adequately to the research question and stated objectives.

\section{Action plan}

The action plan encompassed a total of four sessions with two sessions developed per week (See Appendix 3). Each 90 minute session centred on encouraging students to speak in English, to develop videos, and to subsequently present them to their classmates. Initially, in sessions one and two, the students practised their oral delivery without the video recording tool. During the rest of the intervention, in sessions three and four, students used their smartphone video recording tools. Finally, the recorded video-clips were delivered by the students to the teacher via e-mail or pen drive. Considering all the elements mentioned above, this action research attempted to improve the English language fluency or the participants, particularly with regard to speaking skills, through the use of the smartphone video recording apps. David Nunan's 
(2009) concept of speaking fluency is used in this study: 'the extent to which the speaker uses the language with few hesitations or unnatural pauses, false starts, word searches, etc' (p.55).

\section{Stages of the action research plan}

In order to achieve the aim of the action research study described in this paper and to answer the posited research question, a plan for the investigation was developed in six sessions (See Appendix 3) that included the four main stages of the action research cycle: plan, act, observe and reflect (McAteer, 2013).

A pilot session was conducted on a convenience sample of six EFL $6^{\text {th }}$ graders who were tested at different levels of English proficiency. The students also evinced characteristics similar to the convenient sample chosen for the study. The participants for the pilot study were selected strategically according to the observations made by the English teacher during EFL lessons. This group of 6 students (11 years old) performed a speaking activity using their smartphone video recording applications. This pilot sample produced a short dialogue about their favourite TV shows. This conversation was guided by a set of questions. They recorded their dialogues and were finally asked to provide feedback about the activity. The researcher observed and took notes on this oral communication assignment. The observations made with the pilot group were taken into account in designing and conducting the intervention and to improve the action plan implementation with the final sample of $7^{\text {th }}$ grade participants. The next four sessions involved $7^{\text {th }}$ graders and were related to the oral communication assignment they were tasked with creating and recording through their smartphones screen recording apps. The fifth session encompassed a focus group interview with the participating students to assess their perception of the effectiveness of this methodology.

\section{Ethical considerations}

Before this study was conducted, the parents of the participating students were provided with a consent form to allow the students recording themselves in the oral communication task they would be asked to perform. The parents were informed in detail about the process of the intervention to avoid any obstacles with regard to the age and privacy of the students and to obtain the signed consent of the guardians of the participating students for permission to conduct the study (See Appendix 2).

\section{Data collection techniques}

The data collection techniques used in this research study included the results of a pre- and post-speaking assessment as well as a focus group interview.

\section{Pre-speaking activity}

The pre-speaking activity was developed by the students before using the video recording app in accordance with the teacher's guidelines. The participants were required to talk about their favourite TV show or programme and to include aspects such as the name of the TV show, its nationality, its segments, their favourite part of the show and their reasons for selecting it over other shows. The task presentation of the whole group was expected to last 4 minutes, and each participant was given between 30 seconds to 1 minute to perform individually (see Appendix 4). The oral activity performance was assessed on an individual basis through the use of an adapted analytic rubric created by Zutell $\mathcal{E}$ Rasinski (1991) (See Appendix $1)$. The rubric criteria included expression and volume, phrasing, smoothness and pace. Each criterion was scored according to four categories: Exemplary (4), Accomplished (3), Developing (2) and Beginning (1). Every student was assessed for each criterion, and the 16 points represented the highest score they could obtain (see Appendix 1). The instrument described in a comprehensive way the knowledge and skills to be effectively developed by the learners and could efficiently test the level of proficiency and fluency the students had attained in English language speech delivery.

\section{Post-speaking activity}

The post-speaking activity was executed through the use of the smartphone video recording once 
students had completed their assignment and had presented their TV show videos to their classmates. In congruence with the pre-speaking activity assessment, the participants were again assessed individually using the same adapted analytic rubric with the same criteria. The students participated in the video recording in groups of 3 to 4 students and as before, each student was required to speak fluently in English for about 30 seconds to 1 minute during the video recording related to the TV show (See Appendix 5).

The main purpose of the task was to identify the extent to which the English language fluency of the participants had improved after the short video recordings were produced in which the students showcased their videos to the class.

\section{Focus group}

The focus group comprised of six students. According to Barrios \& Costell (2004), the most effective results are yielded by focus groups with between 2-8 participants. Morgan (1992) suggests that variety in either the participants or the range of topics increases the participants' responses and achieves the purpose of the focus group. The participants were required to address a total of nine open questions that attended to three different dimensions: their general opinion on the smart video recording app, their perception of the video recording app in terms of the enhancement of their English speaking fluency and the effectiveness of the video recording app.

As Krueger and Casey (2000) have noted, focus groups are intended to promote a comfortable atmosphere of disclosure in which people can share their ideas, experiences and attitudes about a topic. Hence, the aim of this focus group was to explore the perception of the participants vis-à-vis the usefulness of the method of assigning short video recordings in increasing their English language fluency.

The comments provided by the participants in the focus group were transcribed and analysed through a thematic analysis in which specific themes emerged.

\section{Data analysis techniques}

Two techniques of data collection were used: simple percentage analysis, and thematic analysis.

\section{Simple percentage analysis}

This technique displays the data in terms of percentages, which is also used to compare statistical data (Judd, McClelland, \& Ryan, 2011). Hence, it was used to compare the performance of participants at both the pre-speaking stage (without the use smart recording video app) and post-speaking stage (with the use of smart recording video app) to achieve the research aim of identifying the extent to which the English speaking fluency of participants had improved after the short video recording session. All the data collected were tabulated as graphs and tables displaying the analysis per criterion. The obtained scores were taken into account to compare the changes in fluency before and after the recording task.

\section{Thematic analysis}

According to Braun and Clarke (2006), a thematic analysis is 'a method for identifying, analysing and reporting patterns within data.' (p.79). In qualitative research, a thematic analysis is imperative and must be conducted in a rigorous and methodical manner to yield meaningful and useful results (Nowell, Norris, White, \& Moules, 2017).

The audio recorded interview of the focus group was analysed through the transcription of the processed data. The aim of this assessment was to determine the students' perceptions regarding the usefulness of using smart recorded videos to improve fluency in English. The data obtained from the focus group interview with participants was scrutinised and the most relevant ideas that emerged from the transcripts were selected. Thus, the comments made by the participating students were categorised into three main dimensions: perceptions of video recordings made via the smart video recording apps; the enhancement of English language fluency; and the effectiveness of the video recording as a learning tool. The collected data were tabulated according to these three dimensions. 


\section{Findings}

The primary objective of this research was to assess the effectiveness of the methodology of using smartphone video recordings apps to increase the English speaking fluency of students. The data analysis will be detailed separately, in accordance with the specific objectives of the study.

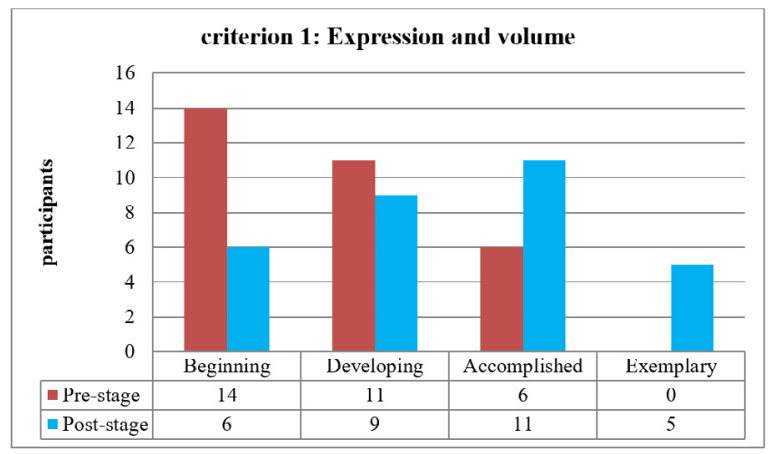

Figure 1. provides a comparative view of participants' performance observed in the expression and volume criteria in both the pre and the post English speaking assessment task.

A significant change is observed in the poststage assessment. $19 \%$ (6) of the students were placed in the beginning category, 29\% (9) were placed in the developing stage, $36 \%$ (11) were grouped in the accomplished category while $16 \%$ (5) were positioned in the exemplary stage. A clear decrease was noted in the number of students ranked in the first two categories (beginning and developing) which are considered the lowest; in parallel, a significant increase was evinced in the accomplished and exemplary classifications. In the post-activity assessment, 5 students were placed in the exemplary group while none had achieved this level at the pre-recording assessment.

Figure 2 displays information regarding participant performances in the phrasing criterion. This assessment demonstrates that students were mostly placed at the beginning level (14 students, or $45 \%$ ) before the intervention. After the intervention occurred, this number decreased significantly from 14 to 6 students. The number of students placed in the developing group was enhanced to $7 \%$ with the addition of two more students. The accomplished classification evinced a significant increase of four students at the post-activity stage, a 33\% increase for this category. From having no students placed in the exemplary category in the pre-activity assessment, 2 participants managed to achieve this enhanced fluency after using the smartphone video recording app.

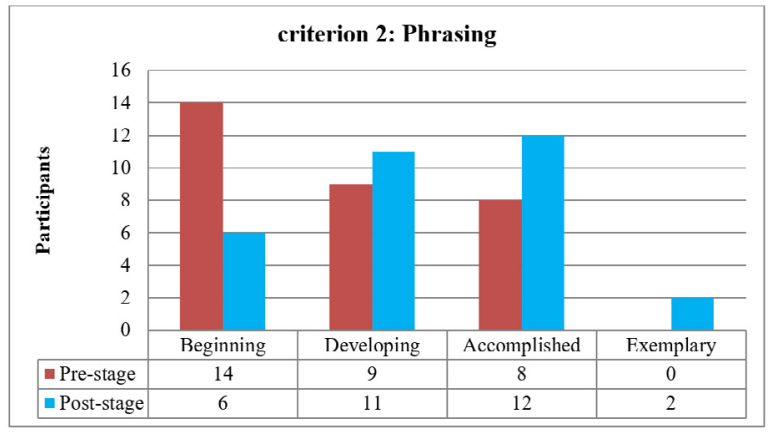

Figure 2. Comparison of students' speaking performance according to the Phrasing criterion.

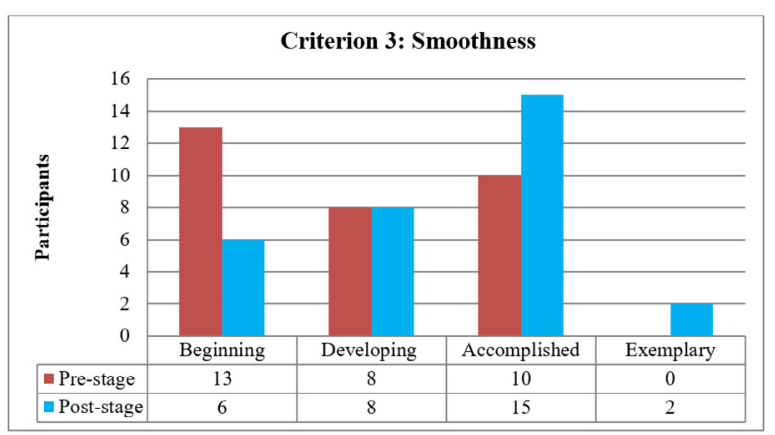

Figure 3. Comparison of students' speaking performance according to the Smoothness criterion.

Figure 3 outlines participant performances in the smoothness criterion, comparing the preand post- speaking activity assessments. For this criterion, the sample universe was originally divided into 19\% (6 students) beginners, $26 \%$ (8 students) at the developing stage, $49 \%$ (15 participants) accomplished students, and 6\% (2 students) exemplary level participants.

In effecting the comparison, a 33\% improvement was observed in the accomplished category with increased from 10 students (pre- 
activity assessment) to 15 students (post-activity assessment). An increase was also observed in the exemplary category with gained two participants from none. No significant change was observed for this criterion for the developing category; however, the number of beginners decreased radically as with the other criteria, from 13 to 6 .

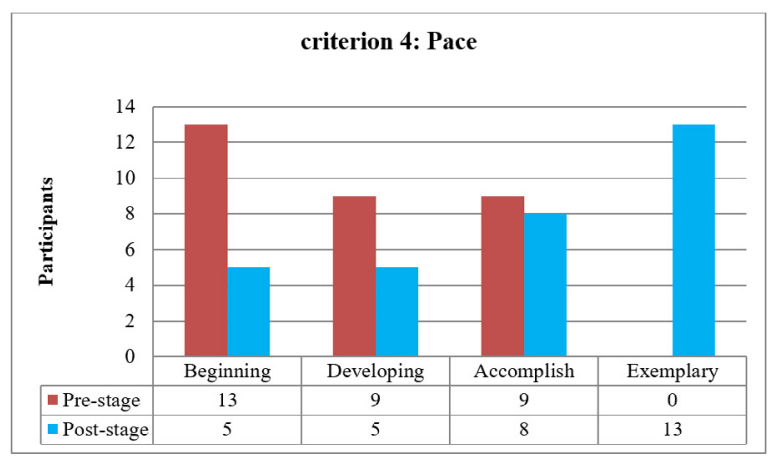

Figure 4. Comparison of students' speaking performance according to the Pace criteria.

Figure 4 displays participant performance assessments for the pace criterion. Initially, five students $(16 \%)$ were placed in the beginning category, 5 (16\%) were positioned in the developing stage, 8 (26\%) were ranked in the accomplished category and 13 students (42\%) were adjudged as exemplary. The post-activity assessment exhibits a noticeable increase, specifically in the upper level exemplary category that was achieved by 13 participants after using the video recording app.
At the pre-activity stage, no students had been positioned in this category.

The focus group interview was conducted after the video recording action plan was fully implemented and the subsequent analysis of the results is based on relevant thematic information obtained from the transcripts of the students' comments, which were grouped into two main dimensions: their opinions on the video recording tool as a means of improving their English language fluency, and the effectiveness of the application.

\section{Dimension 1: Student opinions on the smart video recording app in improving English language fluency}

With respect to the dimension the video recording tool as a means of improving their English language fluency, participants mainly expressed positive comments such as their speaking fluency improved significantly since the tasks were related to their own interests. They also stated they enjoyed recording their videos through smart phone apps since it helped, especially when they were required to repeat terminology to achieve the correct pronunciation. On the other hand, some students expressed negative opinions on varied aspects. They claimed that the use of this app had not changed the way they spoke, and one student also added that she suffered from a panic attack.

Table 1. Student Opinions on Improvement in English Fluency.

\begin{tabular}{|l|l|l|}
\hline Dimension 1 & Frequency & Participant's responses \\
\hline $\begin{array}{l}\text { Self-improvement in English fluency } \\
\text { through video recording }\end{array}$ & 2 & $\begin{array}{l}\text { P4: 'Si yo lo encontré... que estaba bien porque yo no soy muy } \\
\text { bueno pronunciando inglés y al repetir las palabras me sirvió } \\
\text { mucho...' } \\
\text { P1: 'Sí, porque uno cuando iba leyendo como que se iba } \\
\text { aprendiendo las palabras y como el significado' }\end{array}$ \\
\hline $\begin{array}{l}\text { Positive opinions on using the video } \\
\text { recording tool }\end{array}$ & 2 & $\begin{array}{l}\text { P2: 'Siiii notablemente!' } \\
\text { P3: 'Sii yo creo que si, como también eran cosas que nosotros } \\
\text { queríamos...' }\end{array}$ \\
\hline $\begin{array}{l}\text { Negative opinions on using the video } \\
\text { recording app }\end{array}$ & 2 & $\begin{array}{l}\text { P5: 'No, porque no mejoró en mí' } \\
\text { P6: 'No, porque tengo pánico escénico' }\end{array}$ \\
\hline
\end{tabular}


Dimension 2: The ease and difficulty of working with smartphone video recording applications

Of all the comments provided by students in the focus group interview, the themes that emerged most frequently through the dimension pertained to the ease of use or the difficulties in utilising the smartphone video recording apps. All the students expressed in different ways that the 'editing' process was an easy aspect for them. On the other hand, all the participants also articulated the difficulty of the process of video recording and the number of times they had re-record their presentations.

\section{Analysis and discussion of results}

Advances in educational technology have transformed teaching practices and also altered the way students learn. This research area is just emerging in Chile, specifically with respect to the use of smartphones as an interactional learning tool in language learning classrooms to support speaking activities through video recording sessions (Sevari, 2012).

The information presented by this research proposes a valuable pedagogic perspective by investigating how smartphone video recording apps can be turned into effective didactic resources through which to develop the English speaking fluency of $7^{\text {th }}$ grade students.

The findings of this study indicate that a significant improvement in the speaking fluency of students can be obtained in the levels defined in the assessment rubric criteria (Developing, Accomplished and Exemplary). For this study, a prominent enhancement was observed in the pace criterion, particularly at the exemplary level.

This outcome corroborates what many pieces of research have previously proposed (Gromik, 2017; Sihem, 2013; Baleghizadeh \& Oladrostam, 2010; Keddie, 2018; Mercado, 2017) with regard to the benefits of students using smartphones and video cameras to record themselves. This activity accords students the potential to create something memorable, meaningful and enjoyable during their language learning and offers learners the possibility of advancing their oral communication skills, especially since students use apps and smartphones frequently in their daily lives, both within and outside the classroom.

The findings from the focus group interview also indicated that students were in general positively inclined toward the use of video recordings as a resource to improve their speaking fluency. They further expressed that that the video recordings had

Table 2. Participant responses about the ease or difficulty of using video recording apps.

\begin{tabular}{|c|c|c|}
\hline Dimension 2 & Frequency & Participants' responses \\
\hline $\begin{array}{l}\text { Ease of use of the smartphone video } \\
\text { recording app }\end{array}$ & 6 & $\begin{array}{l}\text { P1: 'Editar' } \\
\text { P2 “Quedarse hasta tarde... } \\
\text { P3 "Lo más fácil ayudarse del traductor google para } \\
\text { escuchar las pronunciaciones } \\
\text { P4: Lo más fácil fue hacer el comercial del agua } \\
\text { P5: Lo más fácil fue editar. } \\
\text { P6: Lo más fácil fue taparme con mi pelo... }\end{array}$ \\
\hline $\begin{array}{l}\text { Difficulties in using smartphone video } \\
\text { recording apps }\end{array}$ & 6 & $\begin{array}{l}\text { P1: Grabar bien... así como serio... } \\
\text { P2: Yo creo que lo más difícil fue que algunos coordinan } \\
\text { bien el día de juntarse... } \\
\text { P3: Lo más difícil grabar la parte del comercial ya que no } \\
\text { me acordaba... } \\
\text { P4: y lo más difícil no reírse } \\
\text { P5: Lo más difícil fue grabar, porque les costaba mucho } \\
\text { pronunciar bien y tuvimos que grabar la toma como } 20 \\
\text { veces. } \\
\text { P6: Tratar de no pelear con la Millaray }\end{array}$ \\
\hline
\end{tabular}


helped them improve their English speaking fluency since they were required to work repeatedly on their vocabulary, their pronunciation, and the elaboration of phrases.

\section{Limitations of the study}

The first limitation of the study is related to the number of mobile phones used in the action plan to execute the assigned task. Only one smartphone was allowed per group during the video recording sessions in keeping with school regulations and to avoid distractions in other classes. This action limited the amount of time participants could expend on performing their oral communication tasks as they were given fewer opportunities of repeating their speaking scenes. Students could have performed the tasks better with more repetitions and re-recordings if more than one smartphone was available to groups during the intervention sessions.

The second limitation pertains to the technical difficulties faced by two groups in their voice recordings, the editing programme, the lights, and other elements. In conclusion, two groups found it problematic in some aspect to create their videos.

The third inadequacy concerns the paucity of time for the intervention process, which was applied through a mere handful of sessions. For this reason, students were required to spend extra time to record the videos at home and outside the purview of the teacher's supervision.

The fourth constraint relates to the environments in which the recording sessions were held: the groups had to prepare their scenes in different empty rooms. Fortunately, the school provided enough space where participants could practice and record their videos during classes. However, all the groups (8) had to accomplish modifications and record them at their homes after school.

\section{Conclusion}

Smart technology has often been criticised in schools for causing disruption and interfering with the learning process. Nonetheless, many studies have demonstrated its effective results in education. Smartphones are now considered tools that support and enhance the process of classroom learning when they are used appropriately and under the supervision of teachers. The video recording camera tool is one of the five most effective used smart technologies in the classroom. It has been advised by students and is reported to be as one of the most easily used and powerful methods for learning and instruction (Adeboye, 2016). Language educators should not disregard the use of video recording applications in camera smartphones and should consider the incorporation of digital video recordings in their lessons to enhance the fluency of the oral communication of EFL learners (Göktürk, 2016).

This present research endeavour empirically indicates the benefits of using video recording applications in mobile phones with cameras. Students affirmed their enthusiasm for using this tool and confirmed their felt benefits in attaining a degree of fluency through the activity that was conducted for this study. In the focus group, most students recounted their perceived benefits: the vocabulary repetitions, recall of words and phrases, pronunciation modifications, and multiple video recordings had supported their fluency. Some participants did present some negative issues of video recording presentations: technical difficulties, the limiting of one video smartphone camera per group for use in the task; and the lack of adequate time to record and edit their videos. The pre- and post- activity assessments of fluency also underlined the positive effects of the proposed tool on the English oral communication of most of the students, specifically in the pace criterion identified in the analytic rubric. At the post-activity stage, $42 \%$ (13 students out of 31) of the sample was adjudged at the highest or exemplary level on this measure.

It is certainly necessary to guide students and to prepare educational institutions to incorporate technological devices to perform educational purposes so that learners are given access to increased opportunities of becoming educated through the use of current teaching methodologies, updated technological tools and devices that form an integral part of the everyday life of students. 


\section{Recommendations}

In conducting future research on implementing video recording apps as projects in EFL classrooms, educators must consider both the positive and results and the limitations of the present research endeavour and to incorporate new methods or techniques with which to work. Additionally, technology is one of the main aspects to contemplate in further studies on using the video recording tools available to young people in the current environment. Therefore, the school or educational institutions where future studies are conducted must provide enough classrooms, computers lab access, Internet access, and parental consents that allow students to work with smartphones or tablets that may be also used as tools because these also incorporate video camera apps.

It is recommended that future researchers should develop their investigations over an increased number of sessions to obtain more effective data on the improvement registered in the oral communication fluency of their participants. Therefore, the research time allotted for video recording sessions must be longer than three lessons to appropriately observe the enhancements in the abilities of students over more time.

The video recordings must be supervised and monitored by the researcher in every session to avoid future technical difficulties that can affect the sound quality and thus the findings of fluency.

\section{References}

Adeboye, D. (2016). 5 Effective uses of mobile technology in the classroom. ELearning Industry. Retrieved from https://elearningindustry.com/5-uses-mobiletechnology-in-the-classroom.

Ahmadi, D. M. R., \& Reza, M. (2018). The use of technology in English language learning: A literature review. International Journal of Research in English Education, 3(2), 115-125.

Attewell, J. From research and development to mobile learning: Tools for education and training providers and their learners. Retrieved from http://www.mlearn. org.za/CD/papers/Attewell.pdf.
Bahadorfar, M., \& Omidvar, R. (2014). Technology in teaching speaking skill. Acme. International Journal of Multidisciplinary Research, 2(4), 9-13.

Baleghizadeh, S., \& Oladrostam, E. (2010). The effect of mobile assisted language learning (MALL) on grammatical accuracy of EFL students. Mextesol Journal, 34(2), 1-10.

Barrios, E. X., \& Costell, E. (2004). Review: Use of methods of research into consumers' opinions and attitudes in food research. Food Science and Technology International, 10(6), 359-371.

Berners-Lee, T. (2000). Tejiendo la red: El inventor del World Wide Web nos descubre su origen (No. 04; BMR, TK5105. 888 B4.).

Byrne, D. (1986). Teaching oral English. Cambridge: Cambridge University Press.

Crystal, D. (1977). Advanced conversational English. London: Longman.

Diyyab, E. A. (2014). Using a multimedia-based program for developing student teachers' EFL speaking fluency skills. Journal of Faculty of Education-Benha University, 25(99 P3), 1-28.

Ministerio de Educación Chile. (2004). The English Opens Doors Program Experience. Retrieved from http:// centrodevoluntarios.cl/the-english-opens-doorsprogram/

Gilroy, M. (2004). Invasion of the classroom cellphones. Education Digest.

Glenn, R. J. (1996). Using Video To Enhance Content and Delivery Skills in the Basic Oral Communication Course: Summarizing the Uses and Benefits.

Goh, T., \& Hooper, V. (2007). To TxT or not to TxT: That's the puzzle. Journal of Information Technology Education, 6, 441-453.

Göktürk, N. (2016). Examining the effectiveness of digital video recordings on oral performance of EFL learners. Teaching English with Technology, 16(2), 71-96.

Gromik, N. (2017). Smartphone-based learning in the Japanese ESL classroom: A case study report. Cambridge Scholars Publishing.

Housen, A., Kuiken, F., \& Vedder, I. (Eds.) (2012). Dimensions of $L 2$ performance and proficiency: Complexity, accuracy and fluency in SLA, 32. John Benjamins Publishing.

Judd, C. M., McClelland, G. H., E Ryan, C. S. (2011). Data analysis: A model comparison approach. Abingdon: Routledge.

Jung, S. H. (2006). The use of ICT in learning English as an international language [Doctoral Dissertation]. 
Jurich, S. (2001). ICT and the teaching of foreign languages. TechKnowLogia, Knowledge Enterprise, Inc.

Katchen, J. E. (1991). Video cameras in EFL classrooms: Utilizing the new technology.

Keddie, J. (2018). Video recorders in the classroom. Retrieved from http:/www.teachingenglish.org.uk/ node/14010/videodiscussion

Kirkgoz, Y. (2011). A blended learning study on implementing video recorded speaking tasks in taskbased classroom instruction. Turkish Online Journal of Educational Technology - TOJET, 10(4), 1-13.

Koponen, M., E Riggenbach, H. (2000). Overview: Varying perspectives on fluency. In Perspectives on fluency (pp. 5-24). MI: University of Michigan.

Krueger, R. A., E Casey, M. A. (2000). Overview of focus groups.focus groups: A practical guide for applied research, 3-19.

Kukulska-Hulme, A. (2012). Language learning defined by time and place: A framework for next generation designs. In Left to my own devices: Learner autonomy and mobile-assisted language learning (pp. 1-20). BRILL. Chapter One.

Lansford, L. (2014). Six reasons to use video in the ELT classroom.Cambridge Conversation. Retrieved from http://www.cambridge.org/elt/blog/2014/03/sixreasons-use-video-elt-classroom

Lawless, L. (2018). What is fluency? How long does it take to be fluent in French? Retrieved from https:// french.kwiziq.com/blog/what-is-fluency/

Lenhart, A., Ling, R., Campbell, S., \& Purcell, K. (2010). Teens and mobile phones: Text messaging explodes as teens embrace it as the centerpiece of their communication strategies with friends. Pew Internet $\mathcal{E}$ American Life Project.

Lynch, T., \& Maclean, J. (2003). Effects of Feedback on Performance: A Study of Advanced Learners on an ESP Speaking Course. Edinburgh Working Papers in Applied Linguistics, 12, 19-44.

Mareco, D. (2018). Reasons today's students NEED technology in the classroom. Retrieved from https:// www.securedgenetworks.com/blog/10-reasons-todays-students-need-technology-in-the-classroom, 10.

McAteer, M. (2013). Action research in education.sage.

Mercado, L. (2017). Technology for the Language Classroom: Creating a 21st century learning Experience. London: Macmillan International Higher Education.

Morgan, D. L. (1992). Designing focus group research. In M. A. Stewart, F. Tudiver \& M. J., Bass, E.V. Dunn, \& P.
G. Norton (Eds.), Research methods for primary care, 2. Tools for primary care research (pp. 177-193).

Murphy, T., \& Woo, L. (1998). Videoing conversation for student evaluation: Educational video's diamond in the rough. The Language Teacher, 22(8), 21-24.

Nation, P. (1989). Improving speaking fluency. System, 17(3), 377-384.

Park, H. (2005). Design and development of a mobile learning management system adaptive to learning style of students. Proceedings of the 2005 IEEE international workshop on wireless and mobile technologies in education.

Resultados (2005). Retrieved from https://www. agenciaeducacion.cl/estudios/biblioteca-digital/ resultados/. Agencia de Calidad de la Educación

Schmidt, R. (1992). Psychological mechanisms underlying second language fluency. Studies in Second Language Acquisition, 14(4), 357-385.

Sevari, K. (2012). The role of mobile phones in education and instruction of classroom materials. Advanced Education, 1(1), 19-22.

Sihem, S. (2013). Using Video Techniques to Develop Students' Speaking Skill.aSkripsi. University of Biskra.

Skehan, P. (2009). Modelling second language performance: Integrating complexity, accuracy, fluency, and lexis. Applied Linguistics, 30(4), 510-532.

Sloan, K. (2015). The role of technology in the classroom. Retrieved from https://www.oakhillschool.org/es/ node/11174. Oak Hill School.

Sun, Z., Lin, C. H., You, J., Shen, Hj, Qi, S., \& Luo, L. (2017). Improving the English-speaking skills of young learners through mobile social networking. Computer Assisted Language Learning, 30(3-4), 304-324.

Taylor, K. R. (2008). Still trying to "make the call" on student smartphones. Principal Leadership: Middle School Edition the Kentucky Communication Association.

Tuğa, B. E. (2013). Reflective feedback sessions using video recordings. ELT

Zimmer, S. (2018). Perfect speed pacing for presenting and speaking to groups-Read the self-expression blog to improve speaking skills. Retrieved from http://www. self-expression.com/speaking-freely/perfect-speedpacing-for-presenting-and-speaking-to-groups/

Zutell, J., E Rasinski, T. V. (1991). Training teachers to attend to their students' oral rea ding fluency. Theory into Practice, 30(3), 211-217. 


\section{Appendices}

\section{Appendix 1: Fluency Analytic Rubric}

\begin{tabular}{|c|c|c|c|c|}
\hline & Beginning & Developing & Accomplished & Exemplary \\
\hline $\begin{array}{l}\text { Expression and } \\
\text { Volume }\end{array}$ & $\begin{array}{l}\text { Speaks in a quiet voice } \\
\text { and the utterance does } \\
\text { not sound like natural } \\
\text { language. }\end{array}$ & $\begin{array}{l}\text { Speaks in a quiet voice. } \\
\text { Speech sounds natural in } \\
\text { some areas but does not } \\
\text { give the overall effect of a } \\
\text { natural language. }\end{array}$ & $\begin{array}{l}\text { Speaks generally in an } \\
\text { appropriate volume and } \\
\text { with adequate expression. } \\
\text { Occasionally, the expression } \\
\text { slips and does not provide } \\
\text { the overall effect of a natural } \\
\text { language. }\end{array}$ & $\begin{array}{l}\text { Speaks with appropriate } \\
\text { volume and expression. } \\
\text { Speaker sounds natural } \\
\text { in the target language, } \\
\text { which matches the } \\
\text { learner's interpretation of } \\
\text { the passage. }\end{array}$ \\
\hline Phrasing & $\begin{array}{l}\text { Speaks word-by-word } \\
\text { and frequently in } \\
\text { monotone. }\end{array}$ & $\begin{array}{l}\text { Speaks frequently in } \\
\text { two- or three-word } \\
\text { phrases, places improper } \\
\text { stress, and intonation is } \\
\text { inappropriate. }\end{array}$ & $\begin{array}{l}\text { Speaks with a mixture } \\
\text { of run-ons, pauses mid- } \\
\text { sentence for breath, and } \\
\text { exhibits some choppiness; } \\
\text { however, evinces reasonably } \\
\text { accurate stress and } \\
\text { intonation. }\end{array}$ & $\begin{array}{l}\text { Speaks with accurate } \\
\text { phrasing, mostly with } \\
\text { adequate attention to } \\
\text { expression, stress and } \\
\text { intonation. }\end{array}$ \\
\hline Smoothness & $\begin{array}{l}\text { Speaks with frequent } \\
\text { and extended pauses, } \\
\text { hesitations, false starts, } \\
\text { sound-outs, repetitions, } \\
\text { and/or multiple } \\
\text { attempts. }\end{array}$ & $\begin{array}{l}\text { Speaks with extended } \\
\text { pauses or hesitations } \\
\text { that are frequent and } \\
\text { disruptive. }\end{array}$ & $\begin{array}{l}\text { Speaks with occasional } \\
\text { breaks in the smooth rhythm } \\
\text { because of difficulties } \\
\text { with specific words and/or } \\
\text { structures. }\end{array}$ & $\begin{array}{l}\text { Speaks smoothly overall } \\
\text { with some breaks, } \\
\text { but resolves word and } \\
\text { structure difficulties } \\
\text { quickly, usually through } \\
\text { self-correction. }\end{array}$ \\
\hline Pace & $\begin{array}{l}\text { Speaks slowly and } \\
\text { laboriously. }\end{array}$ & Speaks moderately slowly. & $\begin{array}{l}\text { Speaks in an uneven mixture } \\
\text { of fast and slow pace. }\end{array}$ & $\begin{array}{l}\text { Speaks consistently at } \\
\text { a conversational pace, } \\
\text { using an appropriate rate } \\
\text { of speech throughout. }\end{array}$ \\
\hline
\end{tabular}

Adapted from Zutell E Rasinski (1991) 


\section{Appendix 2: Parent's Consent}

\section{AUTORIZACION PARA PARTICIPAR PROYECTO EN LA INNOVACION DE L ENSEÑANZA DE INGLÉS}

Yo.

RUT

domiciliado(a)en

En mi calidad de padre/madre y/o apoderado(a) autorizo a (nombre y apellido del alumno) (RUT) que pertenece al establecimiento educacional (nombre del colegio) para participar en la intervención de proyecto denominado USING SMARTPHONE SCREEN RECORDING APP FOR ENHANCING ENGLISH LANGUAGE FLUENCY, el cual estará organizado y guiado por profesor(a) de inglés durante. Los participantes serán intervenidos durante 5 sesiones de una hora y treinta minutos cada una aproximadamente. El plan de la presente investigación acción consistirá en que los alumnos puedan grabar videos en inglés con el apoyo del investigador (profesora). Dicho proyecto busca un aumento en las habilidades de comunicación oral (fluidez) de los alumnos en inglés como lengua extranjera.

Cabe mencionar que todos los datos personales y/o resultados de los alumnos que sean recopilados son absolutamente confidenciales y anónimos, al mismo tiempo dicha intervención busca que el profesional desarrolle competencias más avanzadas y especializadas en su desempeño pedagógico con miras a lograr aprendizajes de calidad en sus estudiantes.

En este contexto, agradeceré a usted tenga bien a autorizar la realización de éste proyecto,

Cierto de su atención se despide cordialmente,

Profesor (a)

Firma apoderado(a)

Fecha de éste documento.

del mes.

del año. 


\section{Appendix 3: Stages of the Action Plan}

\begin{tabular}{|c|c|c|c|}
\hline SESSION & DATE & OBJECTIVE & PROCEDURE \\
\hline $\begin{array}{l}0 \text { Pilot } \\
\text { session }\end{array}$ & May $31^{\text {st }}$ & $\begin{array}{l}\text { To develop a pilot session } \\
\text { toward implementing the } \\
\text { final action plan. }\end{array}$ & $\begin{array}{l}6^{\text {th }} \text { graders students prepare and present a short speaking task } \\
\text { regarding their favourite TV shows by recording themselves through } \\
\text { their smartphone video tools. }\end{array}$ \\
\hline 1 & June $5^{\text {th }}$ & $\begin{array}{l}\text { To inform students about } \\
\text { the research and apprise } \\
\text { them about the meaning of } \\
\text { fluency. }\end{array}$ & $\begin{array}{l}\text { The teacher informs the participants ( } 7^{\text {th }} \text { graders) about the action } \\
\text { research they would be undertaking and explains the meaning of } \\
\text { speaking fluency meant. }\end{array}$ \\
\hline 2 & June $7^{\text {th }}$ & $\begin{array}{l}\text { To obtain the first impression } \\
\text { of the English language } \\
\text { fluency of students for } \\
\text { comparison with assessment } \\
\text { data obtained after the } \\
\text { intervention. }\end{array}$ & $\begin{array}{l}\text { The teacher provides students with instructions and a model. } \\
\text { Students present their video recording drafts to the class. Teacher } \\
\text { corrects some mistakes related to speaking fluency issues identified } \\
\text { during the class presentations. }\end{array}$ \\
\hline 3 & June $12^{\text {th }}$. & $\begin{array}{l}\text { To obtain a second } \\
\text { impression of the student } \\
\text { performances and the } \\
\text { effectiveness of the } \\
\text { smartphone video recording } \\
\text { apps. }\end{array}$ & $\begin{array}{l}\text { Students work in the same groups as in the previous session to } \\
\text { create a second video draft relating to the given assignment. They } \\
\text { practice and record their speeches or dialogues. }\end{array}$ \\
\hline 4 & June $14^{\text {th }}$. & $\begin{array}{l}\text { To analyse student } \\
\text { performances in terms of } \\
\text { their English speaking fluency } \\
\text { assessed through the use of } \\
\text { the video recording tool. }\end{array}$ & $\begin{array}{l}\text { Participants work in their groups in the computer lab, organise their } \\
\text { presentations, complete the final components of their assigned } \\
\text { tasks pertaining to TV shows, and record their presentations using } \\
\text { smartphone video recording apps. The task is graded using the same } \\
\text { analytic rubric that was applied in the first session. }\end{array}$ \\
\hline $\begin{array}{l}5 \\
\text { Focus group }\end{array}$ & June 29th & $\begin{array}{l}\text { To gather information about } \\
\text { the participants' perception } \\
\text { of the use of the video } \\
\text { recording tool as a teaching } \\
\text { method. }\end{array}$ & $\begin{array}{l}\text { The researcher conducts a focus group interview with six participants } \\
\text { as a data gathering tool and explains the aim of the focus group } \\
\text { discussion to the participants. Participants are asked questions about } \\
\text { the video recording sessions and their perceived improvements in } \\
\text { their speaking fluency. The participants' answers, opinions and ideas } \\
\text { are recorded. }\end{array}$ \\
\hline $\begin{array}{l}6 \\
\text { Analysis of } \\
\text { results }\end{array}$ & July 6th & $\begin{array}{l}\text { To compare and contrast the } \\
\text { oral English language fluency } \\
\text { of participants, before and } \\
\text { after the intervention. }\end{array}$ & $\begin{array}{l}\text { The results obtained from the analytic rubric in the first session } \\
\text { (session 1) before the video recording activity and after the } \\
\text { intervention (session 4) are analysed comparatively. } \\
\text { Students responses from the focus group interview are also } \\
\text { compiled, tabulated, categorised, and assessed. }\end{array}$ \\
\hline $\begin{array}{l}7 \\
\text { Reflection }\end{array}$ & July 7th & $\begin{array}{l}\text { To reflect on future changes } \\
\text { in the implementation of the } \\
\text { action research. }\end{array}$ & $\begin{array}{l}\text { The developed action plan is contemplated with a view to future } \\
\text { changes that can be effected in a new intervention. }\end{array}$ \\
\hline
\end{tabular}




\section{Appendix 4: Pre-Speaking Activity Guidelines}

Pre-speaking activity guidelines

Student:

Grade: $7^{\text {th }}$ Date:

\section{SPEAKING ACTIVITY}

\section{BEFORE STARTING:}

1. You need to know the meaning of 'oral fluency':

What do you think it is? Select one of the following alternatives.

a) It is speaking faster to other people

b) It is speaking with excellence in grammar and vocabulary aspects and incorporates a high level of proficiency.

c) It is the ability to speak a foreign language easily and effectively, combined with the ability to effortlessly understand others who use this spoken language.

2. What are the most important aspects of an exemplary oral fluency?

a) Expression and volume, phrasing, smoothness and pace

b) Expression and volume, phrasing, smoothness and accuracy.

c) Expression and perfect grammar, phrasing, smoothness and pace 


\section{INSTRUCTIONS}

1. Select a TV show category individually

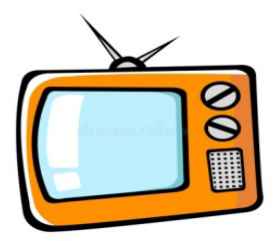
a) Comedy
b) Fantasy
c) Crime
d) Game Show
e) Documentary
f) Music

2. Think about the category and the name of your favourite TV show.

3. You may include some examples of famous shows you know, define the parts of a TV show, why you like this programme, if you have participated in a TV show, famous people who participate in such shows, and add any other information you want.

4. Finally, speak up in front of the class without reading (include all aspects of oral fluency)

5. Duration of speech: between 30 seconds and 1 minute without reading. 


\section{Appendix 5: Post-Speaking Activity Guidelines}

VIDEO TV SHOW/PROGRAMME

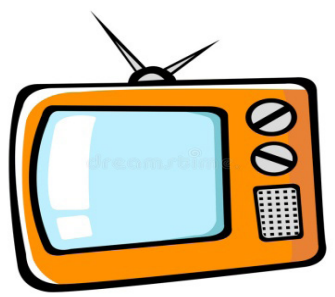

\section{INSTRUCTIONS}

1. Organise your group of 3-4 students to create a video recording of a TV programme.

2. Select the TV show category as a group:

a) Comedy

b) Crime

c) Documentary

d) Fantasy

e) Game Show

f) Music

3. Divide your group's integral roles in creating a script and speaking on the TV show.

4. Select and create the name of your TV programme.

5. Create the TV show elements and script through group work in the computer lab. (Examples: introductory segment, presentation, interview, quiz, musical show, advertising commercial, concluding section and so on) Choose at least three components for your programme.

6. Bring one smartphone per group (check that the video camera app works before bringing the mobile phone to class).

7. Pay attention to your speech fluency and its aspects during the video recording activities (expression and volume, phrasing, smoothness and pace)

8. Speech duration in the video: each participant must speak fluently at least for 30 seconds to 1 minute.

9. Length of the full video: 3 to 5 minutes.

Please read and follow the analytic rubric provided by the teacher. 


\section{GROUP NAME: DATE:}

INTEGRAL ROLES:

1.

2.

3.

4.

\section{TV SHOW/PROGRAMME ROLES}

1. Host:

2. Interviewer:

3. Interviewee:

4. :

\section{GROUP ROLES}

1. Writer:

2. Checker:

3. Technician:

4. :

\section{SHOW/PROGRAMME PARTS}

I. Introduction:

II. Interview:

III. Quiz:

IV. Publicity programme/Advertisement:

V. Conclusion: 
Smartphone Screen Recording Apps: An Effective Tool to Enhance Fluency in the English Language

\section{SCRIPT}

